\title{
Ekososiaalinen
}

\section{sivistys haastaa vapaan sivistystyön}

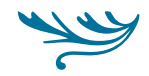

\author{
'Ekososiaalinen sivistys' yhdistää kestävästä kehityksestä \\ huolehtimisen yhteisölliseen vastuuseen, joka vaatii tietojen ja \\ taitojen omaksumisen lisäksi asenteiden ja ajattelutapojen muutosta, \\ sivistymistä. Aihetta käsittelevissä teksteissä ratkaisuksi tarjotaan \\ transformatiivista oppimista. Vaarana on, että ekososiaalisen \\ sivistyksen huumassa unohdetaan perinteinen aikuisten ympäristö- \\ kasvatus ja muut didaktiset lähestymistavat. Etenkin vapaan \\ sivistystyön on uudistuttava vastatakseen sivistyshaasteisiin.
}

EKOSOSIAALISEN SIVISTYKSEN käsite on nopeasti yleistynyt aikuiskasvatuksen alueella. Etsimme käsiteparin sisältäviä aikuiskasvatukseen ja -koulutukseen liittyviä suomenkielisiä tekstejä esimerkiksi Itä-Suomen yliopiston Primolla, Journal.fi-alustalla ja Google Scholar -hakukoneella. Lisäksi kävimme läpi Aikuiskasvatus-lehdessä käytyä, laajemmin kestävään kehitykseen ja aikuisten ympäristökasvatukseen kytkeytyvää keskustelua.

Kirjallisuushakujen pohjalta näyttää siltä, että käsitteen 'ekososiaalinen sivistys' on ottanut ensimmäisenä käyttöön kestävyystutkija Arto O. Salonen vuonna 2012 julkaistussa artikkelissa (Salonen 2012a; sittemmin myös Salonen 2013 ja Salonen \& Bardy 2015) ja samana vuonna yhteisöpalvelu YouTuben videol- la (Salonen 2012b). 'Ekososiaalinen' on vanhempaa perua ja vakiintunut monenlaisten käsitteiden etuliitteeksi. Esimerkistä käy 'ekososiaalinen näkökulma' (esim. Järvelä 1999; ks. myös Helne \& Silvasti 2012), mutta Salonen näyttäisi olevan ensimmäinen, joka on yhdistänyt siihen 'sivistyksen'.

Arvioimme lisäksi käsitteen yleistymistä Googlehauilla. Vaikka hakutapa ei olekaan aukoton, se kertoo, minkä tyyppistä materiaalia aiheesta löytyy eri vuosilta. Ennen vuotta 2015 ei löydy mitään; vanhin käsitteen mainitseva materiaali on vuonna 2015 julkaistu kestävän kehityksen kasvatuksen käsitteistön kehittämishankkeen (https://finto.fi/keko/fi/) julkaisema "KEKO - Kestävän kehityksen kasvatuksen ontologia" (KEKO 2015). Vuoden 2018 jälkeen 
käsite alkaa yleistyä, ja vuoden 2021 tammikuussa Google-haku tuottaa 9120 tulosta: pääosin hankesivuja, opetussuunnitelmia ja blogeja. Ensimmäinen pro gradu -tutkielma näyttäisi Google Scholarin mukaan valmistuneen vuonna 2017. 'Ekososiaalinen sivistys' on siten vuonna 2012 ensimmäisen kerran mainittu ja vuodesta 2018 alkaen nopeasti suosiota saanut käsite.

Etymologisesti 'ekon' taustalla on kreikan oikos, joka tarkoittaa kotia tai taloutta. Se on laajentunut käsittämään myös luonnon toimintaa sekä kestävää elämäntapaa ja kestävää kehitystä. 'Sosiaalinen viittaa ihmisten ja ihmisyhteisöjen toimintaan. Veli Matti Mathlin (2020) tiivistää käsitteiden keskinäisen yhteyden: "Ekososiaalisuus tarkoittaa ekologisten ja sosiaalisten asioiden ymmärtämistä erottamattomaksi kokonaisuudeksi. Ekologinen maailma ympärillämme on osa sosiaalista maailmaamme, halusimme tai emme." 'Sivistys' on näistä kolmesta moniulotteisin käsite, jolle ei ole yhtä määritelmää. Tieteen termipankki (2020) määrittelee sen "kasvatuksen kautta omaksutuksi viisaudeksi, avarakatseisuudeksi ja henkiseksi kehittyneisyydeksi”. 'Ekososiaalinen sivistys' sisältää siis luonnon ja ihmisyhteisöjen toiminnan moninaiset yhteydet ja asettaa yksilöille ja yhteisöille näihin liittyviä uudenlaisia sivistyshaasteita. Tai kuten kestävyystutkijat Arto O. Salonen ja Marjatta Bardy $(2015,4)$ kirjoittavat, ekososiaalisesti sivistynyt ihminen "tunnistaa keskinäisriippuvuuksia ekologisen, sosiaalisen ja taloudellisen todellisuuden välillä". Selkein ekososiaaliselle sivistykselle löytämämme määritelmä on KEKOsanastossa (KEKO 2015, 32):

"Sivistys, johon liittyy inhimillisen kasvun kautta saavutettu ymmärrys ihmisen vapauksista ja vastuista, jotka perustuvat riippuvuuteen luonnosta ja toisista ihmisistä. Ekososiaalinen sivistys auttaa ottamaan ekologiset ja sosiaaliset kysymykset huomioon jokapäiväisessä toiminnassa sekä rakentamaan kestävää tulevaisuutta. Ekososiaaliseen sivistykseen kuuluvat kriittisyys, ajattelun taidot ja kyky asettua muiden asemaan."

Englannin kielellä vastaavaa keskustelua on käyty kahden termin pohjalta: sustainability (esim. Moyer
\& Sinclair 2020) viittaa kestävään kehitykseen, $e c o-$ justice ihmisten riippuvuuteen ekosysteemeistä. Jälkimmäisessä myös tunnistetaan marginaaliryhmiä ja luontoa sortavat valtajärjestelmät ja ylikulutuksen tuottamat haitat syy-seuraussuhteineen.

Päätöksenteossa ja koulutuksessa on otettava huomioon ihmisoikeudet, kulttuuri ja luontoympäristöjen kestävä käyttö. Ekologinen oikeudenmukaisuusajattelu on ulotettu koskemaan erityisesti pedagogiikkaa. (Martusewicz, Edmundson \& Lupinacci 2015, 12-13, 95-134; Washington, Chapron, Kopnina, Curry, Gray \& Piccolo 2018, 372; Foster, Mäkelä, Martusewicz \& Akulukjuk 2019.) Siinä nähdään, ettei luonto voi toimia välinearvona ihmiselle. Luontoympäristöjä tulisi käyttää siten, että siitä ei aiheudu niille kohtuutonta haittaa. Ihmisten itselleen suomia etuoikeuksia tulisi käyttää niin, että ne pohjautuvat ekosysteemien kestävyydelle. (Washington ym. 2018.)

\section{EKOSOSIAALISEN SIVISTYKSEN EDELLÄKÄVIJÖITÄ}

Ennen ekososiaalisen sivistyksen käsitteen käyttöönottoa puhuttiin aikuisten ympäristökasvatuksesta, jolla on pitkät, joskin marginaaliset perinteet. Aiheesta on kuitenkin julkaistu yksi aikuiskasvatuksen vuosikirja, Aikuisten ympäristökasvatus (Kajanto 1992).

Yksi aikuisten ympäristökasvatuksesta huolta kantanut keskeinen vaikuttaja ja ajattelija oli professori Urpo Harva (1910-1994). Hän puhui 1980-luvulta alkaen esimerkiksi ekologisesta humanismista ja "kasvatuksesta vihreään ajatteluun", joita hän piti tärkeinä luonnon turmelemisesta ja rajallisten resurssien tuhlaamisesta syntyvän ekokatastrofin torjunnassa. (Alanen 1994.) Samoihin aikoihin tutkija ja yhteiskuntapoliitikko Pekka Kuusi toi Tämä ihmisen maailma -teoksessaan (1982) esille tarpeen uudelle sivistyskäsitykselle ja elämäntavalle. Hän painotti, että syvällisesti ja maailmaa laajasti näkevät ihmiset voivat käsittää oman roolinsa maailmassa ja nähdä omien toimien merkityksen ympäristölle.

Samanlaisia huolia oli monilla muillakin, mutta ilman selkeää aikuiskasvatuspainotusta. Esimerkiksi kalastaja Pentti Linkola toi esille näkemyksensä teollistumisen haitallisista vaikutuksista yhteiskuntaan, 


\section{SIVISTYST $\ddot{A}$ UHKAAVAT}

\section{KULTTUURIMME SOKEAT}

\section{PISTEET.}

kulttuuriin ja ympäristöön. Linkolan mukaan teollistumisen myötä yhteiskunta yksipuolistuisi, kaupungistuisi ja keskittyisi kuluttamiseen, jonka lieveilmiöinä olivat epäviihtyvyys, tyytymättömyys, katkeruus ja kadehtiminen. Länsimaalainen elämäntapa rappeuttaisi itse itsensä. (Linkola 1960, 23-27.)

\section{MITÄ KESTÄVÄÄ KEHITYSTÄ TUKEVA SIVISTYS ON?}

Kestävää kehitystä tukevasta sivistyksestä on käyty paljon keskustelua Aikuiskasvatus-lehdessä. Pitkän uran sivistystyössä tehnyt Seppo Niemelä (1991) erotti sivistystiedon ja hallitsemistiedon, joista hallitsemistieto pyrkii tekniikan kehittämiseen ja luonnon valjastamiseen, kun taas sivistystieto tähtää ihmisen sisäiseen kehittämiseen. Niemelän mukaan keskeinen rooli sivistämisessä on sivistystyöllä ja kasvatustieteillä, joiden hän kritisoi erkaantuneen sivistyksen perimmäisestä käsityksestä.

Sivistymisprosessissa on kolme vaihetta: Ensimmäiseksi ihminen syventää tietoja, tunnetaitoja, esteettistä ajattelua, käytöstä sekä etiikkaa ja itsenäistyy. Toisessa vaiheessa ihminen tulee tietoiseksi ympäristöstään ja omasta paikastaan siinä. Hän oppii ymmärtämään luontoa ja ekosysteemejä, kulttuureja niin paikallisesti kuin globaalistikin sekä vallitsevia arvoja. Kolmanneksi hän ymmärtää, mistä tähän on tultu, ja näin hänelle avautuvat nykyhetki ja historia sekä luonnon ja lajien tietämys. Ihmiselle aukeaa oma paikkansa maailmassa, ja syntyy ymmärrys tärkeinä pidettävistä asioista. Sivistys antaa työkalut omaan kriittiseen ajatteluun, jolloin "sivistymisessä heikkenee perinteen, yleisen mielipiteen ja muodin ihmistä tiedottomasti ohjaava vaikutus" (mt., 205).

Filosofi Heikki Mäki-Kulmalan (1999, 336-337) mukaan sivistystasomme riippuu kyvystämme asettautua tarkastelemaan itseämme myös kriittisin silmin. Näin voimme huomata, ettei omahyväisyytemme oikeuta ihmisoikeuksien tai luonnon riistoa. Vas- taavalla tavalla Arto O. Salonen $(2013,41)$ kirjoittaa, että "sivistys ilmenee ihmisen käyttäytymisessä avarakatseisuutena, vastuuna ja kykynä muodostaa kokonaiskäsitys käytettävissä olevan tiedon perusteella. Sivistyksen uhkana ovat sellaiset kulttuurissamme olevat sokeat pisteet, joita emme havaitse niiden tavanomaisuuden tai esimerkiksi kiireen kaventaman havainnointikykymme vuoksi”. Huolestuttavaa on, että yhteiskunnan toimintaa luonnehtii jatkuva kiirehtiminen eteenpäin, varmistamatta kuitenkaan suuntaa, johon kannattaa edetä (Joutsenvirta \& Salonen 2020, 12-13).

Tuomas Rantasen (1999) mukaan sivistys antaa eri mielipiteille ja toimille tilaa, ja juuri kilpaileva arvomaailma tekee valituista arvoista vieläkin tärkeämmät. Sivistynyt on tietoinen omista valinnoistaan ja siitä vastuusta, johon omat valinnat tulevaisuudessa kantavat. Professori emeritus Reijo Miettinen (2017, 93) viittaa filosofi J. V. Snellmanin sivistyneen yksilön määritelmään, ”että hän perheenjäsenenä, ammatissaan, kunnassaan, kansakunnassaan, ihmiskunnan suurissa kysymyksissä ymmärtää aikansa vaatimukset”. Miettisen mukaan 2010-luvulla tällaisia suuria kysymyksiä ovat muun muassa ilmastonmuutos ja luonnon tuhoutuminen.

Filosofi Eero Ojanen (2018) korostaa sivistyksen inhimillisyyttä, yksilöllisyyttä ja monipuolisuutta. Sivistykseen kuuluvat suvaitsevaisuus ja kyky arvioida omaa toimintaa. Sivistys on teoissamme ja sanoissamme.

\section{MINKÄLAISIA LUONTOA JA IHMISKUNTAA UHKAAVIA ILMIÖITÄ TEKSTEISSÄ TUNNISTETAAN}

Suomessa ilmastonmuutoksen yhteiskunnalle, yksilöille ja luontoympäristöille aiheuttamista haitoista on tiedetty jo teollistumisen alkuvaiheista, 1800-luvun loppupuolelta lähtien. Tietoisuus riskeistä ei ole saanut aikaan toivottavaa muutosta, sillä suomalaiset ovat Pohjoismaiden kärkeä kuluttamisesta aiheutuvissa hiilidioksidipäästöjen muodostamisessa. Yleisemminkin kansakuntia vaivaa sosiaalinen ja ekologinen sivistymättömyys. (Salonen 2013, 45-46.) Myös OKKA-säätiön suunnittelupäällikkö Erkka Lainisen $(2018,18)$ mukaan suurin syyllinen ilmas- 
tonmuutoksen jatkuvaan etenemiseen on jatkuva talouskasvun tavoittelu ja sen luoma kulutuskeskeinen hyvinvointikäsitys.

Ekososiaalista sivistystä käsittelevien tekstien analyysimme osoittaa, että ajattelun taustalla ovat eri kirjoittajien varsin samankaltaiset huolet lisääntyvistä ekososiaalisista ongelmista, joiden pääsyynä pidetään ihmisten haitallista toimintaa yksilö- ja yhteiskuntatasolla. Huolet on alun perin kuvattu pääosin jo Salosen ensimmäisissä artikkeleissa (Salonen 2012a, 2013; Salonen \& Bardy 2015). Huoliksi on määritelty ilmastonmuutosta ja luonnon tuhoutumista vauhdittavat ilmiöt: individualismi, vaurauden ja talouskasvun tavoittelun pohjalle rakentuva kulutuskulttuuri ja siitä seuraava ylikulutus.

Haitallista toimintaa ja ilmiöitä selittävä ajattelumalli on nimetty teksteissä antroposeismiksi eli ihmiskeskeisyydeksi, joka korostaa ihmisen ylivertaisuutta muuhun luontoon nähden (esim. Pulkki, Pulkki \& Vadén 2019, 77.; Salonen 2018; Siirilä, Salonen, Laininen, Pantsar, Tikkanen \& 2018; Värri 2018). Ihmisen tarpeet menevät kaiken muun edelle, ja ihmistä pidetään kaikin puolin parempana kuin muita eliöitä.

Antroposeismi nähdään voimakkaimpana käyttäytymisemme ohjaajana. Sen mukanaan tuomia ongelmia on muun muassa individualismi, joka murentaa yhteisöllisyyttä ympäristön ja solidaarisuuden kustannuksella. Individualismiin kuuluu jatkuva yhä paremman elintason tavoittelu, joka pohjautuu kulutuskulttuuriin. Työ vie yhä suuremman osan elämästämme, ja työstä saamamme raha käytetään kestämättömään kuluttamiseen. Todellisuudessa perustarpeiden tyydyttämisen ylittävä kulutus tiputtaa pohjan elämältämme, eikä tuota onnea. Jatkuvasti pidentyvät työpäivät vie aikaa siltä, mikä todellisuudessa voisi luoda meille onnea ja sisältöä elämään. Lisäksi työelämän lisääntyneet paineet ovat luoneet kilpailua työstä ja työuupumusta, jotka syövät kansakuntamme hyvinvointia. (Salonen \& Åhlberg 2013, 2; Joutsenvirta \& Salonen 2020.)

Nykyisen ylikulutuksen syyt ovat moninaiset. Niemelä piti yhtenä osatekijänä sitä, että kasvatus korostaa hallitsemistietoa, joka jättää varjoonsa sivistyksen uudistavaan luonteeseen kuuluvan luovuuden, ennakoimattomuuden ja yksilöllisen ainutkertaisuuden. Ilmastonmuutospuheessa tuodaan esille myös teknologia, joka näyttäytyy vaarallisena joutuessaan sivistymättömiin käsiin. (Niemelä 1991.) Niemelän lisäksi professori Veli-Matti Värri (2018, 85 ja 107) on tuonut esille huolen teknologian vaikutuksista ihmisiin ja kestämättömään kuluttamiseen. Samoin Jani Pulkki $(2020,311)$ on todennut, että teknologiset laitteet ja niiden jatkuva käyttäminen häiritsee ihmisen "rauhaantumista", joka on tärkeää varsinaisen minuuden löytämiseksi ja siten välttämätöntä ekososiaalisen sivistyksen omaksumiseksi.

\section{MITÄ RATKAISUJA ONGELMIIN TARJOTAAN?}

Ongelmien ratkaisuiksi kirjoittajat tarjoavat hyvinvointikäsityksen muutosta, kestävyystietoista elämänorientaatiota, systeemiajattelua, vastuullisuutta, kohtuullisuutta, ihmistenvälisyyttä ja eettistä luontosuhdetta. Salosen $(2013,59)$ mukaan hyvinvointikäsityksen tulisi uudistua niin, ettei se rakennu talouskasvun tavoittelulle vaan niin, että ymmärretään vaurauden tavoittelun tuhoisat seuraukset nykyisille ja tuleville sukupolville. Ekososiaalisesti sivistynyt ymmärtää oman onnellisuutensa rakentuvan ihmistenvälisyydelle, jolloin elämän mielekkyys perustuu toimiviin ihmissuhteisiin. Ihmistenvälisyys näyttäytyy yhteiskunnallisena osallisuutena, jossa kaikilla on tilaa osallistua erilaisten yhteisöjen toimintaan ja tulla nähdyksi ja hyväksytyksi niissä, toisistamme välittäen ja tiedostaen toimintamme vaikutukset toisen ihmisen hyvinvointiin (Salonen 2013, 60). Yhteisöön kuulumisen tunne ja merkittävät ihmissuhteet vähentävät tarvetta materian omistamiseen. Ihminen kasvaa täyteen mittaansa kanssakäymisissä muiden ihmisten kanssa. Luottamus ja yhdessä toimiminen vähentävät kilpailun ja ahneuden tarvetta. (Salonen \& Bardy 2015, 9-10; myös Laininen 2018, 30; Värri 2018.)

Vastuullisuus on ekososiaalisen sivistyksen yksi peruspilari. Ekososiaalisesti sivistynyt ihminen tavoittelee vastuullisuutta luonnosta ja muista ihmisistä, sillä hän ymmärtää oman toimintansa vaikutukset luontoon ja yhteiskuntaan. Suhteemme luontoon on kiinteä ja olemme siitä riippuvaisia - emme voi tuhota ympäristöä ja olettaa, että siitä riittäisi riistettävää 


\section{KoHTUULLisUUdEN}

\section{OMAKSUNUT IHMINEN}

TAVOITTELEE MATERIAALISEN

VAURAUDEN SIJASTA

HENKIST $\ddot{A}$ KASVUA.

ikuisesti. Kun luontoympäristöt rapautuvat, rapaudumme itsekin, samoin ihmistoiminnasta riippuvainen talouselämä. (Salonen \& Bardy 2015; Salonen 2013, 44.)

Ekososiaalisesti sivistynyt ymmärtää, että vastuu on globaalia, sillä arkiset valintamme vaikuttavat monesti toiselle puolelle maailmaa, kun teollisuus siirtyy kehittyviin maihin. Vastuullisuutta on tiedostaa, mistä ostettu tuote on peräisin, kuinka se on valmistettu ja kuka sen on valmistanut. Vastuullisuutta on myös elämän tarkastelu tulevien sukupolvien näkökulmasta - niille on turvattava samanlaiset tai paremmat mahdollisuudet hyvään elämään planeetallamme. Vastuullisessa maailmasuhteessa luonnonvarojen käyttöä ohjaavat kierrätys, kestävyys ja paikallistalouden tukeminen.

Kohtuullisuudessa ymmärretään se, mikä on riittävästi. Kuluttamisessa omia haluja on tarkasteltava kriittisesti: tarvitsenko tosiaan tätä asiaa vai pärjäisinkö ilman? Kohtuullisuuden omaksunut ihminen on ymmärtänyt ylikuluttamisen aiheuttamat psyykkiset ja ekologiset haittatekijät ja tavoittelee materiaalisen vaurauden sijasta henkistä kasvua, aineettomia palveluita ja sosiaalisia suhteita. (Salonen \& Bardy 2015, 9; Salonen 2013, 59-60.) Lisäksi Värri (2018) tuo esiin eettisen luontosuhteen, jolle koko yhteiskunnan tulisi rakentua. Ihmisellä on kyky tietoiseen olemiseen ja ajatteluun, jolloin hänellä on avaimet oman toimintansa pohdintaan - tulemme luonnosta ja elämme luonnosta.

Raisa Foster, Arto O. Salonen ja Sami Keto (2019, 123 ja 135) puhuvat ekososiaaliseen sivistykseen rinnastuvasta kestävyystietoisesta elämänorientaatiosta, johon sisältyy pedagoginen malli. "Kestävyystietoinen ihminen on ekososiaalisesti sivistynyt ihminen, jolla on toimintatahtoa ratkaista omanäköisesti niitä ekososiaalisia jokapäiväisen elämän ja tulevaisuuden ongelmia, joista on tullut tietoiseksi”. He määrittelevät kolme ydinelementtiä, jotka kuuluvat kestävyystietoiseen elämänorientaatioon kasvattamiseen. Ensimmäinen on tietoisuus ekososiaalisten ongelmien taustalla olevista syistä. Toiseksi tarvitaan tunteiden ja subjektiivisten kokemusten tunnistamista ja käsittelyä sekä kolmanneksi täyteen ihmisyyteen kasvamista.

Ekososiaalinen sivistys vaatii myös systeemiajattelua, jossa ymmärretään elämän osa-alueiden keskinäisriippuvuudet (Laininen 2018,20) ja tarkastellaan asioiden syy-seuraussuhteita laajemmassa mittakaavassa. Systeemisen ymmärtämisen kautta ajattelumme ristiriitaisuudet paljastuvat, ja ymmärrämme ihmisen roolin ekokriisin luojana ja ratkaisijana (Foster ym. 2019, 135). Vakaan talousjärjestelmän mahdollistavat kestävään luonnonvarojen käyttöön pohjautuva ekosysteemi ja sosiaalinen järjestelmä, joka toteuttaa ihmisyhteisöjen tinkimättömät tarpeet. Näihin kuuluvat esimerkiksi oikeudenmukaisuus, ihmisarvojen toteutuminen ja mahdollisuus elää arvokasta elämää. (Salonen 2014, 7-8). Ekologiset ja sosiaaliset ongelmat kulkevat käsi kädessä, minkä vuoksi niitä tulee tarkastella yhdessä (Salonen \& Bardy 2015, 7-8).

\section{MITEN KASVATTAA EKOSOSIAALISESTI SIVISTYNEITÄ AIKUISIA?}

Suomessa kestävään kehitykseen pyrkivä politiikka näyttää rakentuvan pääosin kuluttajien käyttäytymistä ohjaavien lakien, esimerkiksi jätevesilain, ja veropolitiikan, kuten polttoaineveron tai sähköautojen hankintatuen, varaan. Varsin vähän on huomioitu luontoa vähemmän tuhoavien kansalaisten kasvattaminen. Ympäristöministeriön, valtiovarainministeriön ja opetus- ja kulttuuriministeriön yhteistyölle olisi siis tarvetta. Ekososiaalisen sivistyksen tavoitteet on toki kirjattu varhaiskasvatuksen, perusopetuksen ja lukioiden opetussuunnitelmiin (OPS 2014, OPS 2016, LOPS 2016), mutta muutokseen tarvitaan lisäksi valveutuneita opettajia ja kouluttajia. Värri (2018) ehdottaa ympäristökasvatuksen foorumiksi erityisesti opettajankoulutusta, sillä ilman ekologises- 
ti viisaita kouluttajia opit eivät voi siirtyä peruskouluihin tai toisen asteen koulutukseen. Hän ehdottaa myös, että yliopistojen tulee pohtia perimmäistä tarkoitustaan, joka on "maailmantilan tiedostaminen ja kriittisen ajattelun ja toimintavalmiuksien luominen". (Mt., 127, 134.).

Erityisesti tarvittaisiin kuitenkin aikuiskoulutusta ja ekososiaalisesti sivistyneitä aikuisia. Heidän kulutuskäyttäytymisellään on suurin ja välitön vaikutus, ja heitä on huomattavasti enemmän nelisen miljoonaa - kuin lapsia ja nuoria, joita on miljoona. Koulunsa käyneiden aikuisten ekososiaaliseen sivistämiseen tulisi panostaa huomattavasti nykyistä enemmän. Aikuisten ympäristökasvatusta on Suomessa toteutettu vähän, ja sen pariin hakeutuminen vaatii itseohjautuvuutta. Suomen ympäristöopisto SYKLI tarjoaa tutkintoon johtavaa koulutusta, mutta muilta osin aikuisten ympäristökasvatusta pidetään järjestöjen, esimerkiksi ympäristöjärjestö WWF:n, Suomen luonnonsuojeluliiton ja Greenpeacen sekä yhdistysten tehtävänä.

Vapaassa sivistystyössä varsinaisia ekososiaalisesti sivistäviä kursseja on tarjolla aikuisille ainakin kansalaisopistoissa niukasti, ja nekin ovat lähinnä kierrätys- ja puutarhakursseja (Markkanen ym. 2012, 33; Manninen ym. 2019, 45). Vapaan sivistystyön lakiin vuonna 2010 kirjattu kestävä kehitys on siis muutamien aihetta sivuavien kurssien lisäksi näkynyt lähinnä strategiateksteissä oppilaitosten toimintaa ohjaavana periaatteena ja joinakin kehittämishankkeina. Vapaan sivistystyön kurssitarjontaa ja toteutustapoja tulisi ajatella uudella tavalla, jos ekososiaalista sivistystä halutaan edistää.

Onko koulutustavoitetta kuvaava uusi ekososiaalisen sivistyksen käsite tehnyt karhunpalveluksen perinteiselle koulutusmenetelmälle, jolla tavoitetta, aikuisten ympäristökasvatusta, on tähän asti yritetty - tosin ponnettomasti - saavuttaa? Ekososiaalisen sivistyksen teksteissä ekososiaalisen sivistymisen ainoaksi didaktiseksi lähestymistavaksi tarjotaan transformatiivista oppimista, jolla viitataan lähinnä Jack Mezirowin teoriaan (esim. Laininen 2018; Salonen \& Siirilä 2019; Moyer \& Sinclair 2020). Jotain muutokseen pyrkivää lähestymistapaa toki tarvitaan, koska kestävän tulevaisuuden rakenta- minen vaatii oppimista, joka muuttaa ajattelu- ja toimintatapoja. Mezirowin transformatiivisen oppimisen haasteena on kuitenkin pidetty sitä, miten yksilön tiedostaminen saadaan näkymään myös kestävänä käyttäytymisenä (Koskela 2019), erityisesti yhteisössä (esim. Moyer \& Sinclair 2020, 349). Lisäksi Mezirowin malli on vain yksi monia radikaalin lähestymistavan sovelluksia, sillä muitakin muutosorientoituneita - myös yhteisökasvatukseen soveltuvia - menetelmiä on olemassa. Esimerkistä käy Paulo Freiren vapauttava kasvatus, jossa on Mezirowin lähestymistapaa vahvempi yhteisöpainotus (ks. Manninen, Jetsu \& Sgier 2019).

Radikaali aikuisdidaktinen lähestymistapa on kuitenkin vain yksi monista, ja yksipuolinen rajaus siihen unohtaa neljä muuta aikuisten ympäristökasvatuksen lähestymistapaa: liberaalin, progressiivisen, behavioristisen ja humanistisen (Walter 2009; vrt. Manninen ym. 2007, 110-117). Kriittistä lähestymistapaa myös käytetään suomalaisessa vapaassa sivistystyössä vähän, jos lainkaan (Manninen 2017), joten kynnys ottaa se käyttöön on korkeampi kuin muiden.

\section{LOPUKSI}

Analysoimamme kirjallisuuden perusteella ekososiaalinen sivistys on ihmisten täyteen mittaansa kasvamista ja sivistymiseen pohjautuvaa ymmärrystä omasta riippuvuudesta luontoympäristöihin. Tämä vaatii tiedostavaa muutosta sekä toiminnallista ja yhteisöllistä vastuuta tuottavaa koulutusta ja oppimista. Koulutuksen tulisi tuottaa laaja-alaista ymmärrystä luonnon kiertokulusta, ihmisen kiinteästä suhteesta toisiin ihmisiin, ekosysteemeihin ja yhteiskuntaan, joka laajentaa ihmisen kykyä ajatella syy- ja seuraussuhteita laaja-alaisesti. Arvomaailmassa etusijalla on ekosysteemien suojelu ja arvostus. Asioiden arvoa ei mitata rahalla vaan sillä, tuottavatko ne hyvinvointia ekosysteemille ja kanssaihmisille. Ekososiaalisesti sivistynyt ymmärtää, ettei talouskasvu tarkoita hyvinvointia, vaan hyvinvointi rakentuu aineettomille asioille ja merkityksellisille ihmissuhteille. Talouden tehtävänä on tyydyttää ihmisten perustarpeet luontoa ja ihmisiä kunnioittaen. Kestävän 
kehityksen haasteiden ja ratkaisujen kuvauksissa näyttäisi korostuvan länsimainen talousjärjestelmä ja kuluttaminen. Pitäisikö siis puhua 'ekososioekonomisesta' sivistyksestä?

Ekososiaalisen sivistyksen lisääminen on haastava tehtävä, sillä se vaatii suuria muutoksia yksilöiden ja yhteisöjen nykyisiin ajattelu- ja toimintatapoihin. Aikuiskoulutuksen ja vapaan sivistystyön panostus aikuisten ekososiaaliseen sivistämiseen ei ole läheskään riittävällä tasolla. Uudenlaisen koulutustarjonnan ja didaktisten lähestymistapojen kehittämiseen tulisi siis panostaa. Lisähaasteena on tiedon saamisen ('oppimisen') ja kestävän käyttäytymisen (Koskela 2019) välisen kuilun ylittäminen.

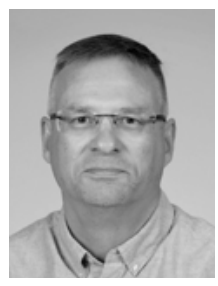

JYRI MANNINEN

$\mathrm{KT}$, professori

kasvatustieteiden ja psykologian osasto

Itä-Suomen yliopisto

aikuiskasvatustieteen dosentti

Helsingin yliopisto

(D) https://orcid0000.org/-00030289-3175

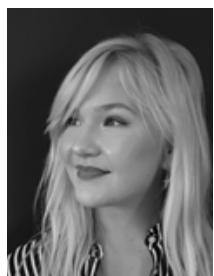

RIINA NOKELAINEN

KK, aikuiskasvatustieteen opiskelija

kasvatustieteen ja aikuiskasvatustieteen asiantuntijakoulutus Itä-Suomen yliopisto

LÄHTEET.

Alanen, A. (1994). Urpo Harva, aikuiskasvatuksen humanistinen filosofi. Aikuiskasvatus, 14(4), 296299. https://doi.org/10.33336/aik.96978

Eskola, K. (1995). Kulttuurinen muutos, elämäntapa ja vapaatavoitteinen sivistys. Aikuiskasvatus, 15(3), 176-179, 229. https://doi.org/10.33336/aik.92330

Foster, R., Mäkelä, J., Martusewicz, R., \& Akulukjuk, T. (2019). Art, Ecojustice, and Education: Intersecting Theories and Practices. London: Routledge.

Foster, R., Salonen, A.-O. \& Keto, S. (2019). Kestävyystietoinen elämänorientaatio pedagogisena päämääränä. Teoksessa T. Autio, L. Hakala \& T. Kujala (toim.) 2019. Siirtymiä ja ajan merkkejä koulutuksessa. Opetussuunnitelmatutkimuksen näkökulmia. Tampere: Tampere University Press, 121-143.

Järvelä, M. (1999). Globalisaatio, hyvinvointi ja kestävä kehitys -hyvinvointi ekososiaalisesta näkökulmasta. Teoksessa P. \& J. Simpura (toim.) Sosiaalipolitiikka globalisoituvassa maailmassa. Helsinki: Gaudeamus, 114-140.

Kajanto, A. (1992). Ympäristökasvatus. Vapaan sivistystyön vuosikirja 33. Helsinki: Kansanvalistusseura.

KEKO (2015). KEKO - Kestävän kehityksen kasvatuksen ontologia. Helsinki: Pääkaupunkiseudun kierrätyskeskus. https://finto.fi/keko/fi

Koskela, I.-M. (2019). Learning and sustainable development - A conceptual review of international literature on education for sustainable development. Reports of the Finnish Environment Institute 32/2019. Helsinki: Finnish Environment Institute.
Kuusi, P. (1982). Tämä ihmisen maailma. Helsinki: WSOY.

Laininen, E. (2018). Transformatiivinen oppiminen ekososiaalisen sivistymisen mahdollistajana. Ammattikasvatuksen aikakauskirja, 20(5), 16-38. https://akakk.fi/ammattikasvatuksen-aikakauskirja05-2018-digitaalinen-erikoisnumero

Lampinen, O. (1998). Kokonaisvaltaista sivistyspolitiikkaa. Aikuiskasvatus, 18(3), 246-247. https://doi.org/10.33336/aik.92516

Linkola, P. (1971). Unelmat paremmasta maailmasta. Helsinki: Into.

LOPS (2015). Lukion opetussuunnitelman perusteet 2015. Määräykset ja ohjeet 2015:48. Helsinki: Opetushallitus.

Manninen, J. (2017). Empirical and Genealogical Analysis of Non-vocational Adult Education in Europe. International Review of Education, 63(3), 319-340.

Manninen, J., Burman, A., Koivunen, A., Kuittinen, E., Luukannel, S., Passi, S. \& Särkkä, H. (2007). Oppimista tukevat ympäristöt - Johdatus oppimisympäristöajatteluun. Helsinki: Opetushallitus.

Manninen, J., Karttunen, A., Meriläinen, M., Jetsu, A. \& Vartiainen, A.-K. (2019). Hyvinvointia ja sosiaalista pääomaa - kansalaisopiston hyödyt osallistujille, kaupungille ja alueelle. Kunnallisalan kehittämissäätiön Julkaisu 23.

Markkanen, M., Lang, T., Lillas, A., Lovio, M., Manninen, J., Takatalo, E., Kamppi, P., Knubb-Manninen, G. \& Pietiläinen, V. (2012). Kansalaisopistojen oppilaitos- ja ylläpitäjärakenteen arviointi. Osaraportti 1: Laatu- ja 
kehittämisavustukset ja ylläpitämisluvat. Koulutuksen arviointineuvoston julkaisuja 58.

Martusewicz, R., Edmundson, J., \& Lupinacci, J. (2011). Ecojustice Education: Toward Diverse, Democratic, and Sustainable Communities. London: Routledge.

Mathlin, V. M. (2020). Ekososiaalinen sivistys auttaa meitä kasvamaan empaattisemmiksi ja poispäin materialismista. Kaleva 8.2.2020. https://www. kaleva.fi/ekososiaalinen-sivistys-auttaa-meitakasvamaan-emp/1653592 (28.1.2021).

Miettinen, R. (2017). Aikuiskasvatus, sivistys ja työn tulevaisuus. Aikuiskasvatus, 37(2), 84-95. https://doi. org/10.33336/aik.88409

Moyer, J. M., \& Sinclair, A. J. (2020). Learning for Sustainability: Considering Pathways to Transformation. Adult Education Quarterly, 70(4), 340-359.

Mäki-Kulmala, H. (1999). Mitä on sivistys? Aikuiskasvatus, 19(4), 336-338. https://doi. org/10.33336/aik.93250

Niemelä, S. (1991). Sivistys ja suoritus. Aikuiskasvatus, 11(4), 204-206. https://doi.org/10.33336/aik.96766

Niemelä, S. (2011). Sivistyminen. Sivistystarve, -pedagogiikka ja -politiikka pohjoismaisessa kansansivistystraditiossa. Helsinki: Kansanvalistusseura \& Snellman-instituutti.

Ojanen, E. (2018). Miten sivistyksestä puhutaan. Aikuiskasvatus, 38(2), 164-165. https://doi. org/10.33336/aik.88341

OPS (2014). Perusopetuksen opetussuunnitelman perusteet 2014. Määräykset ja ohjeet 2014:96. Helsinki: Opetushallitus

OPS (2016). Varhaiskasvatussuunnitelman perusteet. Määräykset ja ohjeet 2016:17. Helsinki: Opetushallitus

Pulkki, J. (2020). Varsinainen minä ja henkisyys ekososiaalisen kasvatusfilosofian aspekteina. Kasvatus, 51(3), 302-316.

Pulkki, J., Pulkki, J., \& Vadén, T. (2019). Ekoterveyskasvatuksen luonnos. Alue ja Ympäristö, 48(2), 69-82. https://doi.org/10.30663/ay.83089

Rantanen, T. (1999). Suomalaiset sivistysnousukkaat ja junttiuden häpeä. Aikuiskasvatus, 19(4), 342-346. https://doi.org/10.33336/aik.93252

Salonen, A. (2012a). Sosiaalinen saneeraus - tie ekososiaaliseen sivistykseen. Kirjassa T. Helne \& T. Silvasti (toim.) Yhteyksien kirja. Etappeja ekososiaalisen hyvinvoinnin polulla. Helsinki: Kelan tutkimusosasto, 134-147.
Salonen, A. O. (2012b). Ekososiaalinen sivistys. YouTube-video. https://www.youtube.com/ watch?v=BX3oZ2M7igU

Salonen, A. O. (2013). Ekososiaalinen sivistys kulttuurin kulmakiveksi. Teoksessa M. Laine \& P. Toivanen (toim.) Kestävä kasvatus - kulttuuria etsimässä. Suomen Kulttuuriperintökasvatuksen seuran julkaisuja 6, 40-69.

Salonen, A. O. (2014). Ekososiaalinen hyvinvointiparadigma - yhteiskunnallisen ajattelun ja toiminnan uusi suunta täyttyvällä maapallolla. Teoksessa J. Hämäläinen (toim.) Sosiaalipedagoginen aikakauskirja 2014. Kuopio: Suomen sosiaalipedagoginen seura, 32-62.

Salonen, A. O. (2018). Kohti avartuvaa oikeudenmukaisuuskäsitystä: Foster, Raisa, Mäkelä, Jussi \&amp; Martusewicz, Rebecca, A. (toim.) (2018). Art, Ecojustice, and Education. Intersecting Theories and Practices. Routledge. 186 sivua. Aikuiskasvatus, 38(4), 336-337. https://doi.org/10.33336/aik.88379

Salonen, A. O., \& Bardy, M. (2015). Ekososiaalinen sivistys herättää luottamusta tulevaisuuteen. Aikuiskasvatus, 35(1), 4-15. https://doi.org/10.33336/aik.94118

Salonen, A. O. \& Joutsenvirta, M. (2020). Sivistys vaurautena. Radikaalisti, mutta lempeästi kohti kestävää yhteiskuntaa. Helsinki: Basam Books.

Salonen, A. O. \& Siirilä, J. (2019). Transformative Pedagogies for Sustainable Development. Teoksessa W. Leal Filho (toim.) Encyclopedia of Sustainability in Higher Education. Springer, Cham. https://doi. org/10.1007/978-3-319-63951-2_369-1

Siirilä, J., Salonen, A. O., Laininen, E., Pantsar, T., Tikkanen, J. (2018). Transformatiivinen oppiminen antroposeenin ajassa. Ammattikasvatuksen aikakauskirja, 20(5), 39-56. https://akakk.fi/ ammattikasvatuksen-aikakauskirja-05-2018digitaalinen-erikoisnumero/

Tieteen termipankki (2020). Sivistys I yleissivistys. http://tieteentermipankki.fi/wiki/Filosofia:sivistys (27.10.2020)

Walter, P. (2009). Philosophies of Adult Environmental Education. Adult Education Quarterly: A Journal of Research and Theory, 60(1), 3-25.

Washington, H., Chapron, G., Kopnina, H., Curry, P., Gray, J., \& Piccolo, J. (2018). Foregrounding ecojustice in conservation. Biological Conservation, 228(228), 367374. https://doi.org/10.1016/j.biocon.2018.09.011

Värri, V.-M. (2018). Kasvatus ekokriisin aikakaudella. Tampere: Vastapaino. 